\title{
Investigations at Nahal Roded 110: a Late Neolithic ritual site in the southern Negev
}

Michal Birkenfeld ${ }^{1, *}$, Liora Kolska Horwitz ${ }^{2}$,

Daniella E. Bar-Yosef Mayer ${ }^{3}$, Jerry Bond ${ }^{4}$, Erika Guttmann-Bond ${ }^{4}$, Linda S. Cummings ${ }^{5}$, Hadas Goldgeier ${ }^{6}$, Maria Krakovsky ${ }^{1}$, Filipe Natalio ${ }^{7}$, Keren Nebenhaus ${ }^{6}$, Frank H. Neumann ${ }^{8}$, Naomi Porat ${ }^{9}$, Louis Scott ${ }^{10}$, Tal Simmons ${ }^{11}$, Talia Yashuv ${ }^{6} \&$ Uzi Avner $^{12}$

Excavations at the Pre-Pottery Neolithic B ritual site of Naḥal Roded 110 in the Southern Negev, Israel, have revealed evidence-unique to this region-for on-site flint knapping and abundant raptor remains.

Keywords: Israel, Negev, Nahal Roded, Neolithic, raptors, cult

\section{Introduction}

In the southern Negev, approximately 370 mountain cult localities (called 'Rodedian' sites) are known (Figure 1). Most are attributed to the Pre-Pottery Neolithic B (PPNB, eighth to sixth millennia BC) and contain unique features and artefacts, such as low, stone-built installations and cells, standing stones, perforated stones and stone bowls (Figure 2; Avner et al.

1 Israel Antiquities Authority, Excavation, Surveys \& Research Department, POB 586, Jerusalem 90014, Israel

2 National Nature History Collections, The Hebrew University, E. Safra-Givat Ram Campus, Jerusalem 9190401, Israel

3 Steinhardt Museum of Natural History, University of Tel Aviv, POB 39040, Tel Aviv 69978, Israel

4 Pontceiliog House, Aber Giar, Llanllwni SA40 9SQ, UK

5 PaleoResearch Institute Inc., 2675 Youngfield Street, Golden, Colorado 80401, USA

6 Institute of Archaeology, The Hebrew University, Mount Scopus Campus, Jerusalem 9190501, Israel

7 Kimmel Center for Archaeological Science, Weizmann Institute, POB 26, Rehovot 7610001, Israel

8 Evolutionary Studies Institute, University of Witwatersrand, Private Bag X3, WITS 2050 Johannesburg, South Africa

9 Geochemistry and Environmental Geology Department, Geological Survey of Israel, 30 Malchei Israel Street, Jerusalem 95501, Israel

10 Plant Sciences Department, University of the Free State, POB 339, Bloemfontein 9300, South Africa

11 Department of Forensic Sciences, Virginia Commonwealth University, 910 West Franklin Street, Richmond, VA 23284, USA

12 The Dead-Sea and Arava Science Center, Tamar Regional Council, Dead Sea Mobile Post 86910, Israel

* Author for correspondence (Email: michal.birkenfeld@mail.huji.ac.il)

(C) Antiquity Publications Ltd, 2019

ANTIQUITY 93 367, e4 (2019): 1-8 


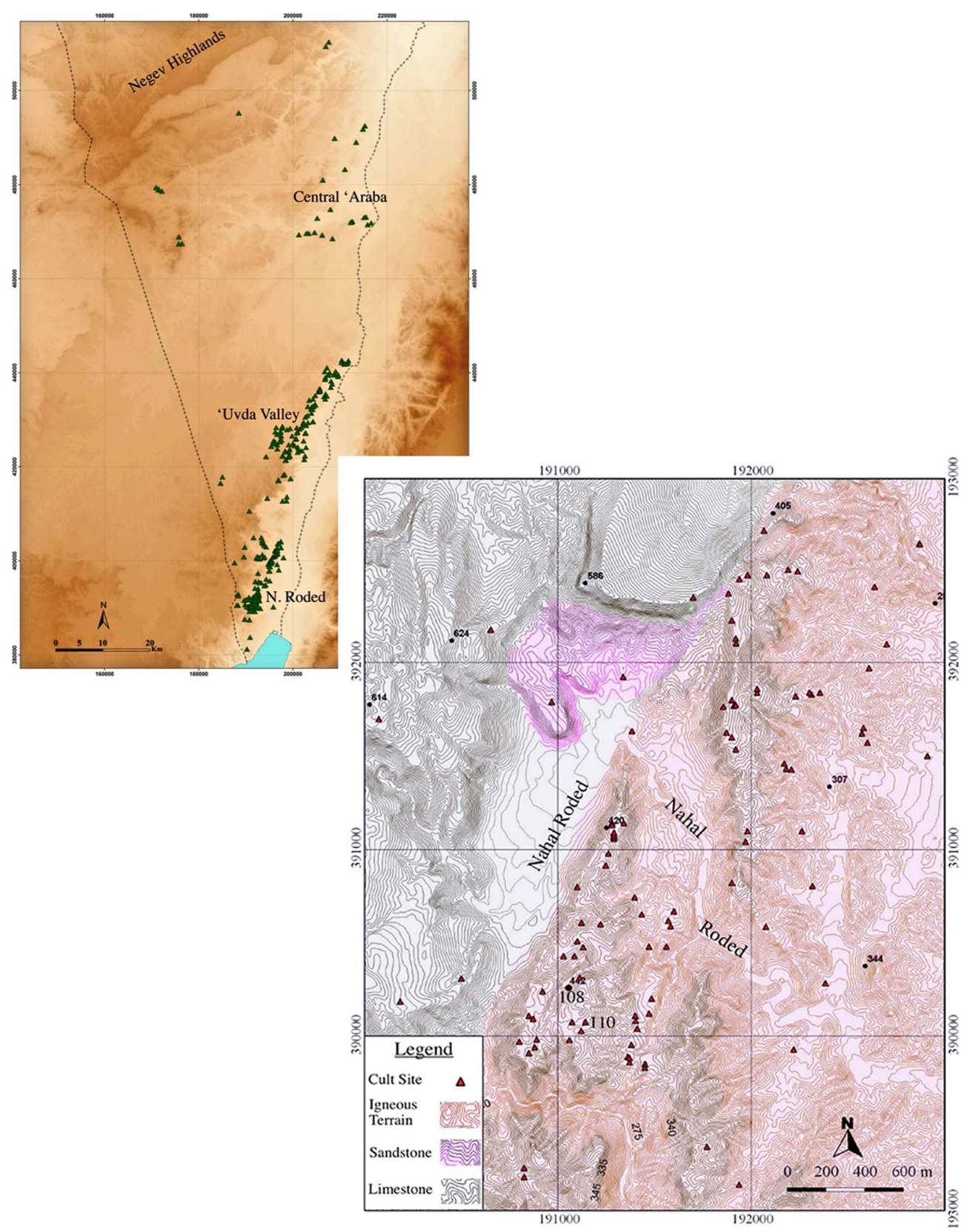

Figure 1. Left) distribution of 'Rodedian' sites in the southern Negev; right) location of Nahal Roded 110 and adjacent sites.

2014). One such cult site, Nahal Roded 110 , situated around $6 \mathrm{~km}$ to the north-west of the city of Eilat, was excavated to assess its chronology, material culture, organic remains and spatial layout, and to elucidate site function and palaeoclimate.

(C) Antiquity Publications Ltd, 2019 


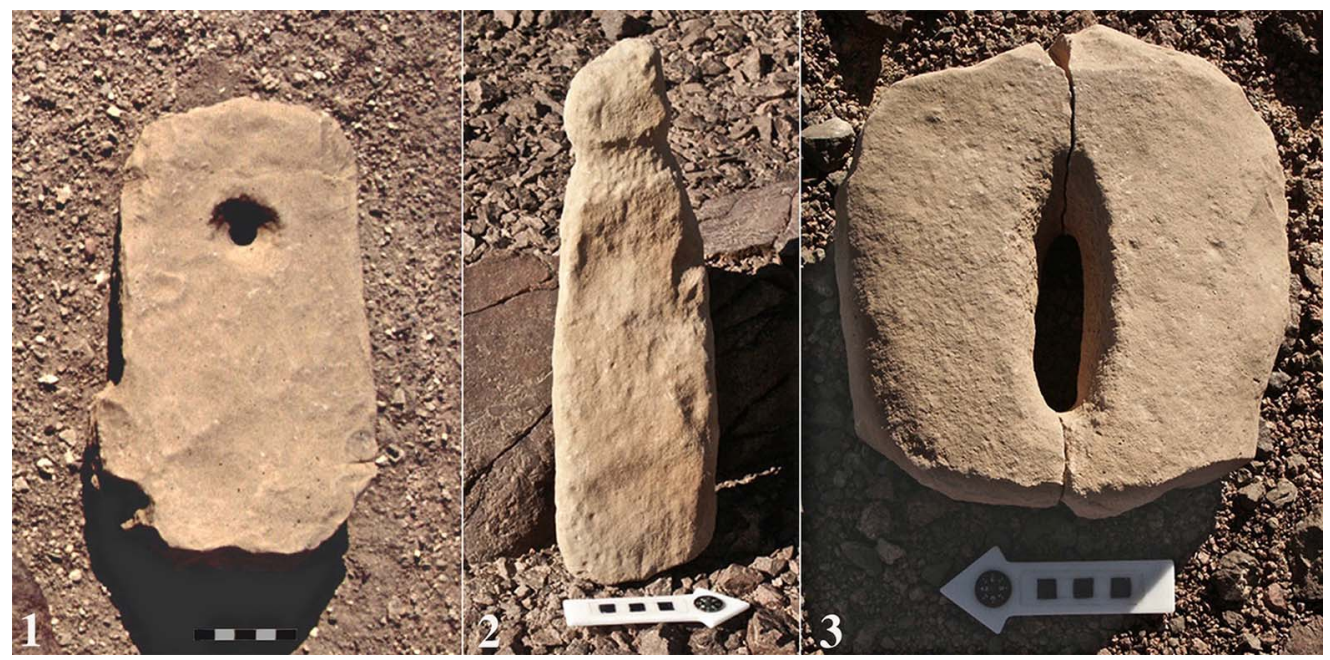

Figure 2. Salient features of Rodedian sites: 1) perforated standing stone (fallen); 2) anthropomorphic image (found fallen); 3) 'vulva-shaped' stone (photographs by U. Avner).

The site covers an area of approximately $150 \mathrm{~m}^{2}$ and lies at an elevation of $420 \mathrm{~m}$ asl within a small, igneous rock embayment. First surveyed in 2004, flint and stone objects were found on the surface, and a collapsed structure and hearth identified (Figure 3; Avner et al. 2014).

\section{Excavation}

In December 2017, a $1 \mathrm{~m}^{2}$ grid was laid out, covering all surveyed features. All surface finds were collected and plotted by square. Three test trenches were opened, traversing both the structure and hearth (Figure 4). Excavation revealed that the deposits are deeper than first assumed, occurring in pockets within the bedrock. The ash-like deposit associated with the hearth is around $5 \mathrm{~m}$ in diameter (Figure 4) and contains large quantities of lithics, faunal remains and charcoal, as well as several built features_-probably small hearths. The excavation ended at a depth of $0.2 \mathrm{~m}$ without reaching bedrock or the bottom of the ash. Excavation of the collapsed structure was limited. It is also around $5 \mathrm{~m}$ in diameter and reaches at least $0.5 \mathrm{~m}$ in depth (Figure 4). The original form is unclear; it may correspond to the round, desert habitations of the PPNB (e.g. Goring-Morris \& Gopher 1983; Ronen et al. 2001), or represent a series of semi-circular walls, similar to ancient desert hunting blinds (e.g. Lönnqvist \& Lönnqvist 2011).

\section{Dating}

Two charcoal samples from the top and two samples from the base of the ash deposit gave average ages of $7000 \mathrm{cal} \mathrm{BC}$ and $7200 \mathrm{cal} \mathrm{BC}$ respectively, confirming the attribution of the site to the Late PPNB. The range of dates and numerous hearths imply that multiple burning events occurred. Samples for optically stimulated luminescence (OSL) dating

(C) Antiquity Publications Ltd, 2019 
Michal Birkenfeld et al.

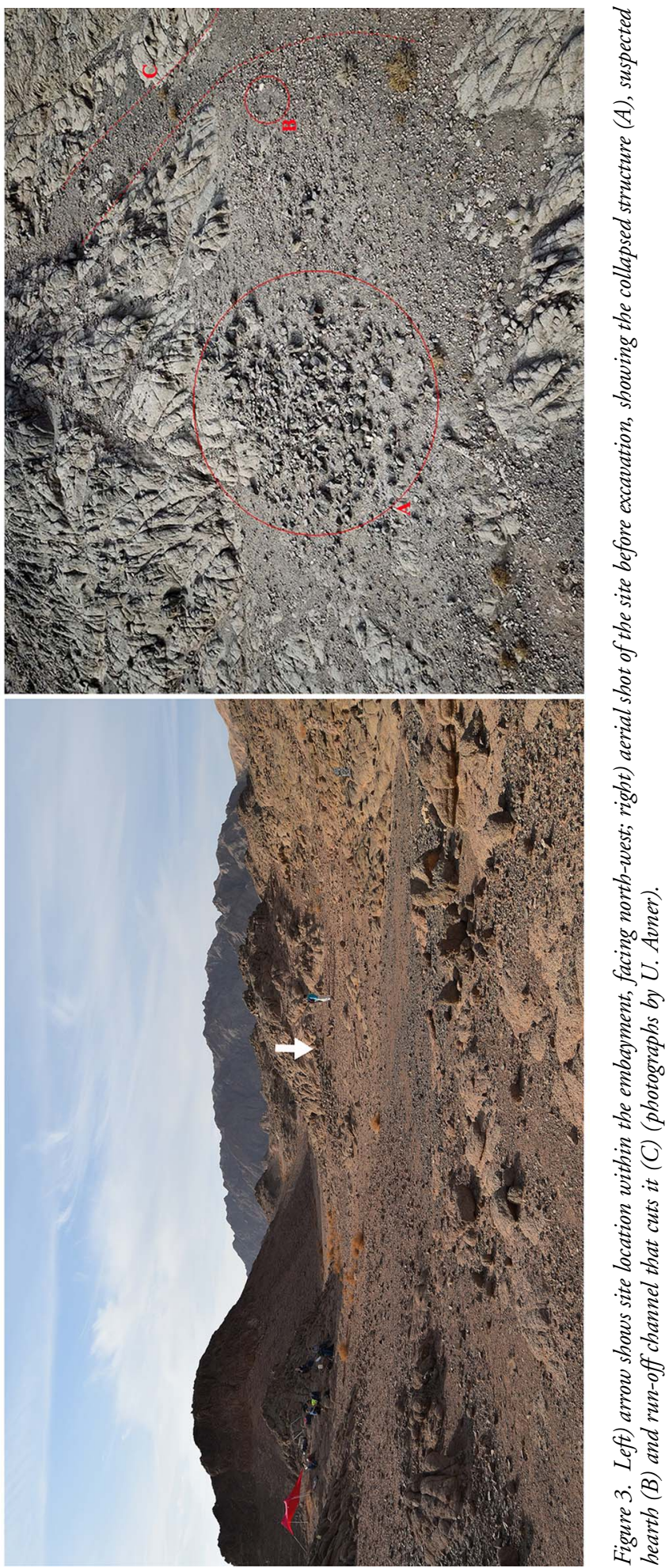

(C) Antiquity Publications Ltd, 2019 


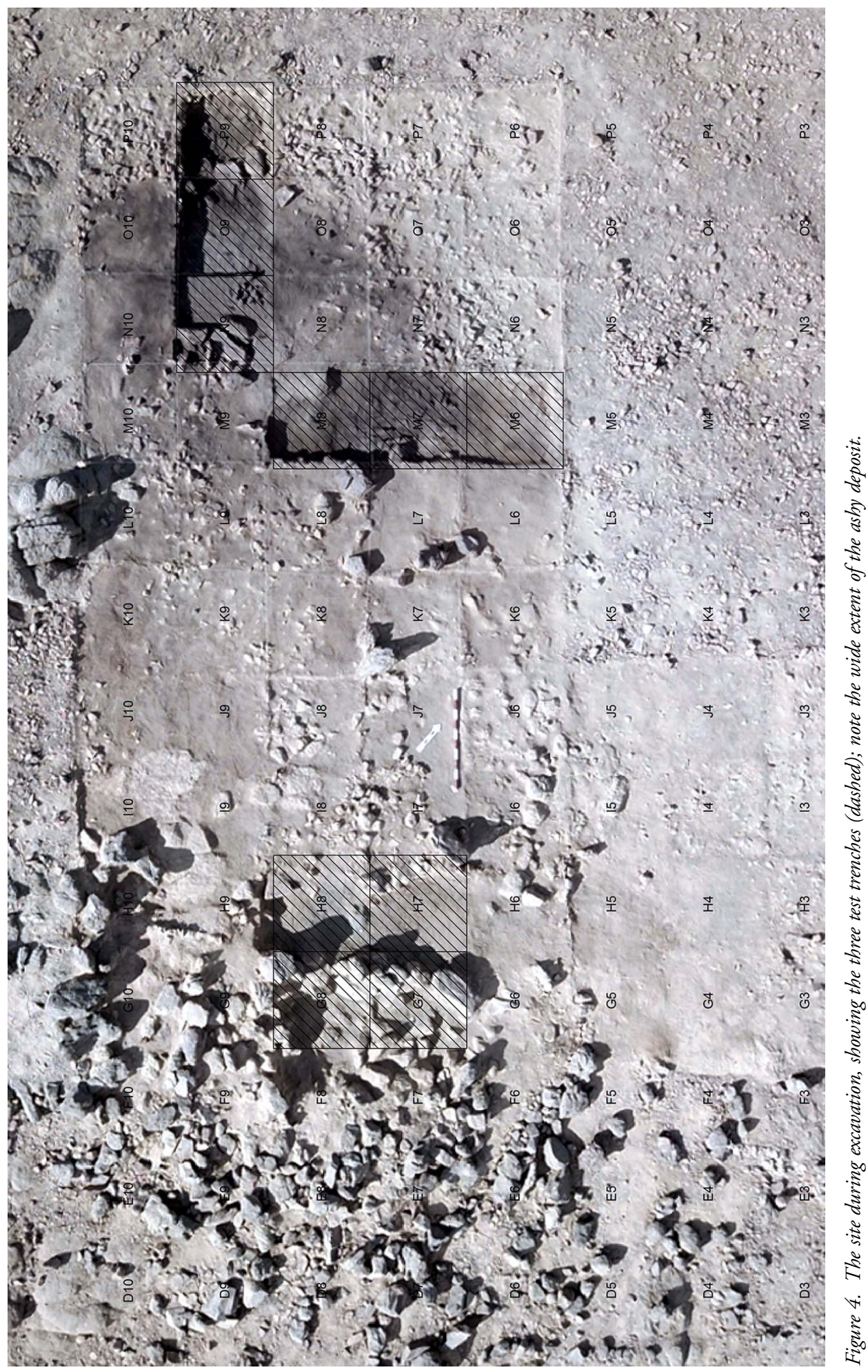

(C) Antiquity Publications Ltd, 2019 

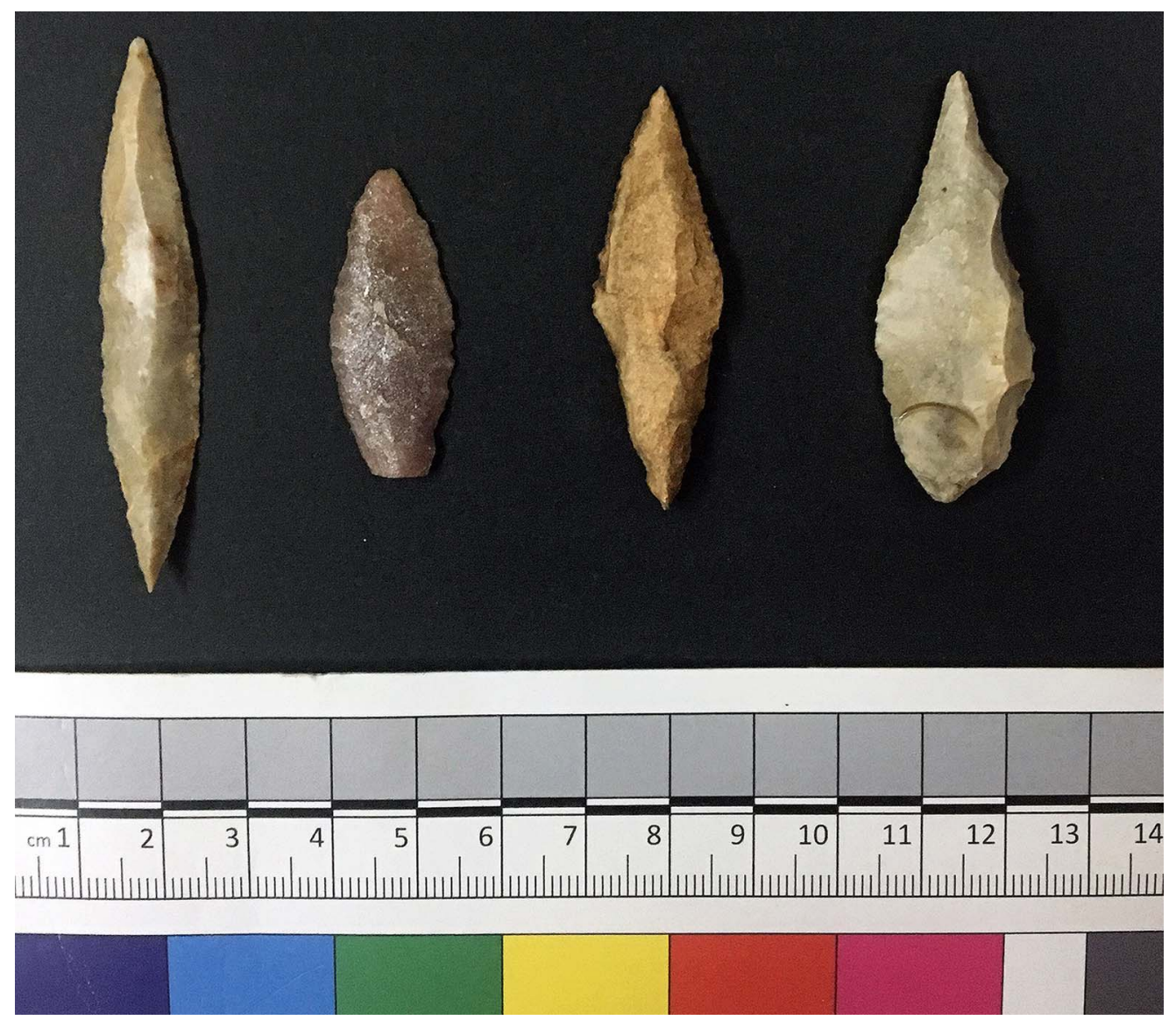

Figure 5. Typical tools from Nahal Roded 110, numbered left to right: 1-3) Amuq points; 4) an elongated borer (photograph by M. Birkenfeld).

were also taken from the base of the ash and the structure, and are in the process of being analysed.

\section{Finds}

The excavated lithics comprised debitage and a few tools - mainly projectile points (Figure 5) of the Amuq type typical of the Late PPNB (Goring-Morris \& Gopher 1983). The high frequency of core-trimming elements indicates that intensive knapping was conducted on site, although no flint sources occur on the igneous mountain. Abundant, well-preserved faunal remains were recovered in and next to the ashy deposit. All remains belong to raptors (superfamilies Accipitridae, Falconidae and possibly Strigidae), with the European honey buzzard predominating (Pernis apivorus) (Figure 6). This connects the site to the spring and autumn raptor migrations that still pass over Eilat (e.g. Leshem \& Yom-Tov 1998). The symbolic association of raptors with death, fertility and rebirth is well established in Neolithic iconography and zooarchaeology (e.g. Peters et al. 2005; Marom et al. 2017). Preliminary results of (C) Antiquity Publications Ltd, 2019 


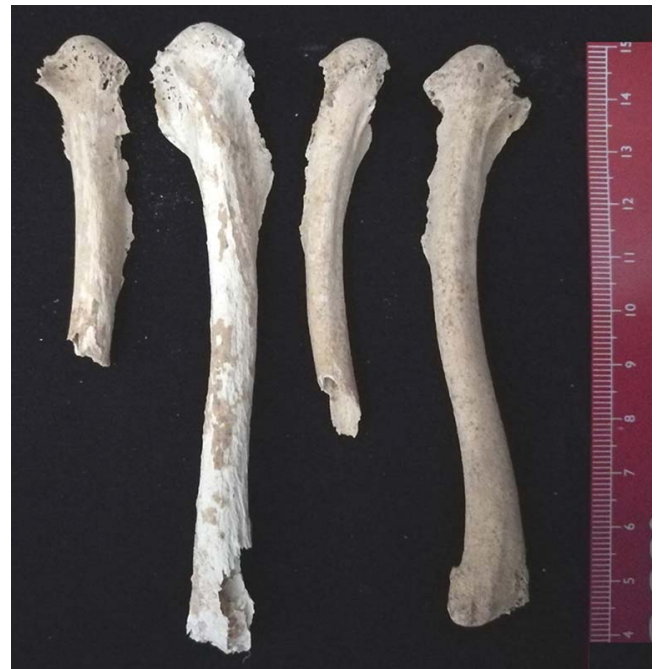

Figure 6. Humeri of the European honey buzzard (Pernis apivorus) from Nahal Roded 110 (photograph by L.K. Horwitz). pollen retrieved from sediment samples yielded typical Saharo-Arabian taxa (e.g. Tamarisk) with elements of Irano-Turanian steppe vegetation (e.g. Asteraceae).

\section{Conclusions}

The excavation at Nahal Roded 110 has yielded many surprises, including the depth and extent of ashy deposits, evidence for on-site flint knapping, preservation of organic remains and the exclusive representation of birds of prey. All are unique features for such a remote site. We should note that all raw materials-flint for tools, limestone for cultic objects, Red Sea shells and wood for kindling - had to be carried up steep and rugged terrain to the site from the wadi below. Nahal Roded 110 either served as a seasonal hunting camp

with the aim of killing raptors during their migration, with ritual activities associated with this endeavour taking place on site, or functioned as a predominantly ritual locality, with the raptors brought as offerings. Whichever is correct, it is clear that Nahal Roded 110 contains physical and spiritual elements that are unique, even when compared to coeval desert sites. The discoveries emphasise the enormous potential of further investigations at this and other Neolithic mountain-top sites in the region.

\section{Acknowledgements}

Research was funded by the Irene Levi-Sala CARE Archaeological Foundation and the National Geographic Foundation. We thank the volunteers who joined us, Avi Gedalia of the Israel Nature and Parks Authority, and Rahamim Shemtov and Johan Fjellstrom for their logistical assistance.

\section{References}

Avner, U., M. Shem-Tov, L. Enmar, G. Ragolski, R. SHem-Tov \& O. Barzilai. 2014. A survey of Neolithic cult sites in the Eilat Mountains. Journal of the Israel Prehistoric Society 44(10): $101-106$.

Goring-Morris, A.N. \& A. Gopher. 1983. Nahal Issaron: a Neolithic settlement in the Southern Negev: preliminary report of the excavations in 1980. Israel Exploration Journal 33: 149-62.

Leshem, Y. \& Y. Yom-Tov. 1998. The magnitude and timing of migration by soaring raptors, pelicans and storks over Israel. Ibis 140: 41-52.
https://doi.org/10.1111/j.1474-919X.1998. tb04539.x

LöNnQvist, M. \& K. LönnQvist (ed.). 2011. Jebel Bishri in focus. Remote sensing, archaeological surveying, mapping and GIS studies of the Jebel Bishri in central Syria by the Finnish project SYGIS (British Archaeological Reports International series 2230). Oxford: Archaeopress.

Marom, N., Y. Garfinkel \& G. Bar-Oz. 2017. Times in between: a zooarchaeological analysis of ritual in Neolithic Sha'ar Hagolan. Quaternary International 464(A): 216-25.

Peters, J., A. von den Driesch, N. Pollath \& K. Sснмidt. 2005. Birds in the megalithic art of 
Michal Birkenfeld et al.

Pre-Pottery Neolithic Göbekli Tepe, southeast Turkey, in G. Grupe \& J. Peters (ed.) Documenta Archaebiologiae 3: 223-34. Rhaden: Marie Leidorf.
Ronen, A., S. Milstein, M. Lamdan, J.C. Vogel, H.K. Mienis \& S. Ilani. 2001. Nahal Reuel, a MPPNB site in the Negev, Israel. Quartär 51-52: $115-56$.

(C) Antiquity Publications Ltd, 2019 